\title{
USING VIRTUAL REALITY DEVICE AS AN INNOVATIVE STRATEGY TO TEACH VOCABULARY FOR TOURISM STUDENTS
}

\author{
I Nengah Laba ${ }^{1}$ \\ ${ }^{1}$ Institut Pariwisata dan Bisnis Internasional, \\ Email: laba.stpbi@gmail.com \\ I Gede Astawa ${ }^{2}$ \\ ${ }^{2}$ Akademi Pariwisata Denpasar \\ Email: gedeastawa@akpar-denpasar.ac.id \\ I Wayan Sonder ${ }^{3}$ \\ ${ }^{3}$ Akademi Pariwisata Denpasar \\ Email: sonderiwayan@gmail.com
}

Received: Oct. 2, 2020 | Accepted: October 27, 2020 | Published: Nov. 2, 2020

Permalink/DOI: https://doi.org/10.53356/diparojs.v1i1.22

\begin{abstract}
ABSTRAK
Penelitian ini bertujuan untuk mengetahui keefektivitasan penggunaan alat virtual reality untuk mengajar kosa kata terhadap siswa. Virtual reality merupakan alat yang memiliki kemampuan untuk menampilkan gambar 3D dan suara yang dikombinasikan dengan dunia nyata secara virtual. Data dikumpulkan melalu artikel jurnal atau sering disebut penelitian kepustakaan. Hasil dari penelitian ini adalah adanya 13 keuntungan dalam penggunaan virtual reality di dalam kelas pariwisata dan penggunaan alat ini sangatlah mudah untuk diimplementasikan oleh guru. Implikasi dari penelitian ini adalah penggunaan alat virtual reality sangat membatu perkembangan guru dan siswa di kelas.
\end{abstract}

Kata Kunci: Inovasi, Virtual Reality, Kosa Kata

\begin{abstract}
This study aimed at figuring out the effectiveness of using virtual reality device to teach vocabulary for students. Virtual reality device is a tool that can show an interactive media in $3 D$ images and sounds combined with the virtual real-world. The data was collected through journal articles or library research. The result of the library research showed that virtual reality device is effective to teach vocabulary for students. From the library was also found that there are thirteen advantages or impacts in conducting virtual reality device in tourism classroom. It was also found that the steps in conducting virtual reality strategy is easy to be implemented and can be done by the teacher properly. It implies the use of virtual device in the classroom will helpful for teacher and students
\end{abstract}

Key words: Innovative, Virtual Reality, Vocabulary 


\section{INTRODUCTION}

Involving the learners in mastering vocabulary strategies is an increasingly important area of investigation in language teaching. Over the past century, there has been a dramatic increase in studies that examined different techniques and suggested theories that claim providing insights in engaging the learners and helping them store and retrieve vocabulary. Consequently, the emergence of the internet has not only revolutionized data, but also the way students engage their bodies and minds with the various visual and auditory content. Nevertheless, Kurt and Bensen (2017) claim the lack of more studies that support integrating technology in vocabulary teaching.

Khan (2016) pointed out that some students in vocational courses face difficulties in knowing and using vocational vocabulary terms in day to day professional life. This indicates a need to examine the newly emerged and constantly developed virtual reality (VR) softwares and test their abilities in transforming the way students learn vocabulary terminologies. The VR headsets designers and advertisers claim they could provide the users with chances to be exposed to authentic practical training without the need to leave the classroom.

Applying this new tool to teaching vocabulary can be considered a shift to immerse the learners in the learning environment. This study also fills a gap in knowledge by contributing to vocational literature by investigating the use of Virtual Reality headsets to help postgraduates retaining vocabulary related to specific course. This article aims to find out the effectiveness of VR in helping students' vocabulary mastery (Madini, 2017).

\section{Problem Identification}

a. Teaching process are lack of innovative media which is able to motivate students to learn

b. Students are getting bored with the conventional teaching given by the teacher

\section{Problem Statements}

a. Can virtual reality be considered as an innovative strategy to teach vocabulary?

b. What are the steps of conducting virtual reality in teaching process?

\section{TEFL in Schools in Indonesia}

English is taught and used as a foreign language in Indonesia. The fact that English is one of the most essential international languages for communication has been acknowledged by the Indonesian government since its independence; therefore, the government has recommended that English become a compulsory subject in secondary schools. The aim of teaching English in schools is based on the Decree of the Minister of Education and Culture No. 060/U/1993 dated 25 February 1993 and the 1989 Constitution on the System of National Education that the final goal of the English subject at the schools is to enable the students to be proficient in English in the globalization era. Meanwhile, Nurkamto (2003) asserts that "the aim 
of the teaching of English in the schools has been to develop the students' communicative competence that would help the students in their university education" (p. 287). However, these aims have never been satisfactorily achieved.

Although English is officially taught throughout secondary schools, competence and proficiency in this foreign language among high schools are generally low (Nurkamto, 2003). Learners find English particularly difficult when they are instructed to state their opinion in English (Nurkamto, 2003). There are only few students who are able to learn English to the next level, especially those who come from the middle and upper socio-economic classes. Such students have "the easy access and opportunity to enhance their English proficiency through private courses, computer-aided language instruction, and exposure through Western influences, TV channels, and foreign movies" (Lie, 2007, p. 3). In addition, Lie (2007) added that outside the academic and professional worlds, English has never been widely used as the lingua franca of the majority of the population. This is because the geographic position of Indonesia is far away from English-speaking countries as well as several particular cultural values that to some extent, cannot motivate students to study English (Nurkamto, 2003).

\section{EFL in Curriculum}

Learning English in primary and secondary (Grades 1 through 12) schools serves two purposes. First, students need to be prepared to read
English texts in their college years. Second, competence in the English language is still used as a determining factor in securing a favorable position and remuneration in the job market. Many job advertisements list a good command of English as one of the top requirements, hence the popularity of private English courses or schools. The academic year is divided into two semesters (Songbatumis, 2017). Starting from Grade 4, English is officially taught for two to four hours a week. At the high school level (Grades 10 through 12), students are streamed into three divisions: The Natural Sciences Stream, the Social Studies Stream, and the Language Stream. For all three streams, English is compulsory and allotted at least four class hours per week. For the Language Stream, the time allotment for English is 11 hours per week. At the university level, many nonEnglish departments require that students take one or two semesters of English for two hours per week (Songbatumis, 2017).

Even though English is officially taught throughout secondary schools and at the university level in Indonesia, competence in this foreign language among high school and university graduates is generally low. Only students coming from the middle and upper socio-economic classes have the easy access and opportunity to enhance their English proficiency beyond that of their peer level through other means such as private courses, computer-aided language instruction (Omieno, Wabwoba, \& Matoke, 2013), and exposure through 
Western-influenced TV channels, foreign movies, and networks with expatriate communities. To provide a picture of the limited access, the cost of an eight-session English course ranges from USD20 to 100 per person while the standard minimum wage is approximately USD60 to 100 per month. It is obvious that English has played a significant role in perpetuating the social stratification in Indonesia. Outside the academic and professional worlds, English has never been widely used as the lingua franca of the majority of the population (Susilo, 2015). Yet, there have been a growing number of speakers of English ranging from near native level to broken English use especially among the young, urban middle-class segment of the population. Inspired by their idolized celebrities from MTV-like stations, which often recruit their reporters and newscasters from among graduates of Western universities, the young Indonesians speak at least chunks of English phrases and utterances as a matter of boosting their urban lifestyle (Susilo, 2015).

According to Susilo (2015) EFL teacher education is the one which prepares not only individuals who are supposed to be successful teachers in the $21 \mathrm{st}$ century learning circumstances, but also life achievers in general in the future. Therefore, key competencies required by all learners within a curriculum structure of the EFL teacher education should meet the following requirements.

a. Courses which will be included in the curriculum should reflect the achievement of all UNESCO pillars.

b. Four domains of achievements as stipulated in the IQF, i.e. 1) attitudes and values, 2) working competence, 3) managerial competence, and 4) field knowledge should be blended in most courses in the curriculum. For instance, domain of attitude and values can be achieved through national courses like Pancasila, Agama (if possible both courses should be offered in English medium instructions), and Bahasa Indonesia. Other main content courses can also manifest this domain, such as Cross Culture Understanding (CCU), Reading Comprehension, Drama, Poetry, or other TESOL courses in which values and attitudes are instilled. In addition, domains of managerial and working competences should also be given though in smaller portions in the forms of supplementary courses such as entrepreneurship, communication of business, etc., but these courses should reflect the trends in the 21 st century skills. For the domain of field knowledge - this must be the main portions of courses - the courses should include literature, linguistics, EFL research, and EFL teaching courses.

c. Courses given in the curriculum should be in various types of EFL Courses, such as seminar or workshop courses; practice-based 
courses; local-context courses, and of course regular courses.

d. In terms of materials and teaching methods, curriculum should allow more humanistic and crosscultural sensitive teaching.

e. EFL curriculum should also accommodate the following skills: career and life skills, initiative-entrepreneurialism, collaboration-teamworkleadership, creativity-innovation, adaptability-effective

communication, and digital literacy.

\section{LITERATURE REVIEW}

Virtual Reality Device is 360 degrees videos made by a collection of cameras or an omnidirectional camera for a specific situation. Images of real-world panorama are recorded from different angles then joined together to form 50 or 60 frames per second using a software. With a resolution of $6 \mathrm{~K}$ instead of $4 \mathrm{~K}$, the different directions of the video can be viewed using head mounted display (HMD) (Yaseen \& Shakir, 2015). Freina \& Ott (2015) proposed that that it originates from the early $60 \mathrm{~s}$ and that it is of two kinds which are: a) immersive and b) non immersive. Immersive VR uses additional tools such as (HMD) or the new VR goggles. These tools help presenting an artificial environment using sounds, 3D images, or other stimuli to give the impression of 'stepping 'stepping 'stepping "stepping inside" a non -physical world. Non -immersive VR uses computer to generate imaginary or real places.

Virtual reality environments have been experienced through different channels in the past by a) joy sticking and key pressing to move a video game character, b) swinging physically when using the Nintendo Wii control to play a game, or c) recently tapping and zooming a smart screen to navigate and view different angles (Madini, 2017).

Teaching Vocabulary is very important because it is the core of the English language itself. Without good vocabularies, students couldn't make a good sentences to convey and it is a must for a teacher to find good combination in teaching vocabularies as a formula to maximize the learning process (Madini, 2017). Involving the learners in mastering vocabulary strategies is an increasingly important area of investigation in language teaching. Over the past century, there has been a dramatic increase in studies that examined different techniques and suggested theories that claim providing insights in engaging the learners and helping them store and retrieve vocabulary. Consequently, the emergence of the internet has not only revolutionized data, but also the way students engage their bodies and minds with the various visual and auditory content. Nevertheless, Kurt and Bensen (2017) claim the lack of more studies that support integrating technology in vocabulary teaching. Khan (2016) pointed out that some students in vocational courses face difficulties in knowing and using vocational vocabulary terms in day to day 
professional life. This indicates a need to examine the newly emerged and constantly developed virtual reality (VR) softwares and test their abilities in transforming the way students learn vocabulary terminologies. The VR headsets designers and advertisers claim they could provide the users with chances to be exposed to authentic practical training without the need to leave the classroom.

\section{METHOD}

In order to answer those questions, the researcher used library research. The researcher used library research method to collect the data and find out the role of mother tongue and used the interview to find out the importance mother tongue's existence in multilingual education, Bali, Indonesia.

\section{DISCUSSION}

Investigating the role of memory in learning vocabulary, recently, movies and videos have been suggested to become integral parts of the curriculum as they proved to led to improve language skills (Yaseen \& Shakir, 2015). The literature has documented the positive effects of integrating videos in English. classes. Madini (2017) highlighted that they effectively motivate learners and stimulate their imagination. Similarly, Yaseen \& Shakir (2015) investigated the relationship between effective learning and students' movie preferences. The 20 students revealed that they preferred subtitles to help them learn vocabulary while watching movies. To support the use of subtitles, Moreover, Kurt's and Bensen's (2017) study reported that the practice of Vine videos improved participants' vocabulary. The results of the posttest and the content analysis of the semi semi-structured interviews revealed that participants enjoyed the experience and were motivated.

Although extensive research has been carried out on the impact of videos on EFL, much less is known about the impact of the new immersive videos or the 360 degrees videos in retaining vocabulary. According to Madini (2017) the content of immersive videos increased rapidly in the past few years due to the emergence of VR tools. To create 360 degrees videos, a collection of cameras or an omnidirectional camera are needed. Images of real-world panorama are recorded from different angles then joined together to form 50 or 60 frames per second using a software. With a resolution of $6 \mathrm{~K}$ instead of $4 \mathrm{~K}$, the different directions of the video can be viewed using head mounted display (HMD) or VR tools (Yaseen \& Shakir, 2015).

Throughout this this paper, the term VR has been used to refer to Virtual Reality environments. Virtual Reality environments are not new, but the term has broadened recently. Freina \& Ott (2015) proposed that that it originates from the early 60 s and that it is of two kinds which are: a) immersive and b) non -immersive. Immersive VR uses additional tools such as (HMD) or the new VR goggles. These tools help presenting an artificial environment using sounds, 3D images, or other stimuli to 
give the impression of "stepping 'stepping 'stepping 'stepping inside", a non -physical world. Non immersive VR uses computer to generate imaginary or real places.

Virtual reality environments have been experienced through different channels in the past by a) joy sticking and key pressing to move a video game character, b) swinging physically when using the Nintendo Wii control to play a game, or c) recently tapping and zooming a smart screen to navigate and view different angles (Madini, 2017). The key element that distinguishes the virtual reality is the user's ability to track movement when wearing the VR tools and hence display different dimensions of surroundings.

\section{Impact of The Strategy}

According to Minocha (2015) Virtual Reality for tourism students can give impact as in the following ways:

a. Integration of tourism students with different learning styles and abilities: A creative child is given an opportunity through Virtual Reality to use his imagination and abilities. It is also an effective technique for those children who find it easier to learn using colors, textures etc. There are various examples in which children who were shy or isolates in the group became accepted due to their skills in technology.

b. Interactive Learning: Rather than using assimilation, as in traditional institutes learning is through interaction and construction. Due to Virtual
Reality, large groups of students are enabled to interact with each other and within a 3-D environment. Student can interact with objects in the environment to understand them and discover more about them. It gives opportunities for group work and peer learning.

c. Makes learning fun and easy: Complex data is represented in such a way that it becomes interesting and simple. Some students in Ireland even recreated a historic place and explored it. Game based learning is motivating because it is fun. A player's gender, weight, etc. does not interfere with their acceptance by other players, which is not there in many educational games.

d. Learning by doing: Theory of Constructivism suggests that learning by doing is the best way of learning. Virtual Reality enables introduction of practical knowledge in the classroom. Students, instead of listening to lectures can get real experience through virtual immersive environment. For example, suppose the topic is related to safety of the school, students can walk around in the virtual environment and take pictures of unsafe points.

e. A different approach to rewards and punishment: Virtual Reality would transform traditional concepts of rewards and assessment. Success is 
acknowledged whereas failures are generally ignored and not punished.

f. It is possible to attend virtual lectures, discussions, exams or labs in 3-D.

g. In learning where safety precautions are required, it is preferable that students interact in a virtual world initially.

h. Study of different cultures: Through cultural immersion some courses are using virtual worlds to recreate exhibits.

i. It helps in visualization of abstract concepts which makes the students have a better understanding.

j. Virtual Reality Projects: For example, students can photograph a site with digital camera and then by using computer software the photos can be stitched together into panoramas. k. Students with special needs: There are various programs that can help students with special needs. One such program helps students with severe hearing impairment learn life skills such as how to cross a street safely. Another program gives students who are disabled, practice in finding their way around schools etc. A program developed in Britain teaches social skills to people with autism.

1. Simulation of computer system: Virtual Reality helps to observe system operation from a number of perspectives.

m. Make learning process exciting, so students are likely to remember what they learn.

\section{Steps in Conducting VR Device for Tourism Students}

These are suggested steps in conducting Virtual Reality Device in tourism classroom.

Table. 1

\section{Comparison of VR teaching Method and Conventional Teaching}

\begin{tabular}{|c|c|}
\hline Virtual Reality Teaching Sequences & Conventional Teaching Sequences \\
\hline $\begin{array}{l}\text { 1. The teacher introduces the } \\
\text { vocabularies which exist in the game } \\
\text { by using picture. It aims also to let the } \\
\text { students know the picture related to } \\
\text { the vocabularies and prepare them for } \\
\text { playing the game. }\end{array}$ & $\begin{array}{l}\text { 1. The teacher introduces the } \\
\text { vocabularies which exist in the } \\
\text { game by using picture. It aims also } \\
\text { to let the students know the picture } \\
\text { related to the vocabularies and } \\
\text { prepare them for playing the } \\
\text { game. }\end{array}$ \\
\hline $\begin{array}{l}\text { 2. The teacher leads the students to make } \\
\text { group in order to accommodate them } \\
\text { in playing the Virtual Reality Device. }\end{array}$ & $\begin{array}{l}\text { 2. The teacher leads the students to } \\
\text { make group in order to } \\
\text { accommodate them in doing }\end{array}$ \\
\hline
\end{tabular}




\begin{tabular}{|c|c|}
\hline & $\begin{array}{l}\text { repetition drill of the related } \\
\text { vocabularies in small group. }\end{array}$ \\
\hline $\begin{array}{l}\text { 3. Teacher tells the instruction of how to } \\
\text { play the game. The instructions are the } \\
\text { students are given the exercise in turn. } \\
\text { They have to answer the question and } \\
\text { if they answer correctly, they get the } \\
\text { points, if they answer incorrect, they } \\
\text { will not get the point and followed by } \\
\text { the other member of other group, the } \\
\text { highest points of the group will be the } \\
\text { winner of the game. }\end{array}$ & $\begin{array}{l}\text { 3. The teacher asks the students to } \\
\text { focus on the picture and the } \\
\text { pronunciation and they will repeat } \\
\text { on and on until they can } \\
\text { pronounce it very well for each } \\
\text { students. }\end{array}$ \\
\hline $\begin{array}{l}\text { 4. The game presents the picture and } \\
\text { vocabularies which will be guessed by } \\
\text { students. }\end{array}$ & $\begin{array}{l}\text { 4. The teacher asks the students to } \\
\text { focus on the picture and the } \\
\text { pronunciation and they will be } \\
\text { repeat on and on until they can } \\
\text { pronounce it very well for each } \\
\text { students. }\end{array}$ \\
\hline $\begin{array}{l}\text { 5. The students start to play the game in } \\
\text { turn with the help from their friends } \\
\text { and teacher. Teacher helps the } \\
\text { students if they find any difficulties. } \\
\text { Their friends help by giving } \\
\text { suggestion in answering the question } \\
\text { in Virtual Reality Device. The game } \\
\text { itself gives instant feedback to } \\
\text { students immediately These } \\
\text { interaction among them will be very } \\
\text { useful to create a new knowledge }\end{array}$ & $\begin{array}{l}\text { 5. The teacher convinces the students } \\
\text { to be confident in pronouncing the } \\
\text { words and concerns on the spelling } \\
\text { also. }\end{array}$ \\
\hline $\begin{array}{l}\text { 6. After they finish the game, the } \\
\text { students are asked to answer the } \\
\text { exercise called matching exercise and } \\
\text { completion (fill in the blank). They } \\
\text { will match the picture with the } \\
\text { appropriate name of the thing } \\
\text { presented and add some letters to } \\
\text { complete the spelling of the name of } \\
\text { things. It aims at investigating their } \\
\text { understanding toward the topic of the } \\
\text { lesson. }\end{array}$ & $\begin{array}{l}\text { 6. Afterwards, if there is no obstacles, } \\
\text { the students will be given exercises } \\
\text { (matching words and picture and } \\
\text { completion or fill in the black) to } \\
\text { re-check their progress of their } \\
\text { understanding. }\end{array}$ \\
\hline
\end{tabular}

\section{CONCLUSION}

VR device can be used as an innovative strategy or median in teaching vocabulary, as mentioned above, VR can help the students to motivate them-selves in learning English and many benefits are given by using VR in the classroom. Even though VR is not new thing in learning but it is still a good progress if it is implemented in classroom, especially in teaching vocabulary because the students are able to remember every single vocabulary which attracts their attention when using VR device. In addition, using VR in teaching vocabulary will ease the teacher to conduct their teaching 
process because they only explain the material in the beginning and let the students play with VR and give the task based on the VR game, then find out the result of the learning. It is not only playing the game but also understanding the progress of students' learning.

Why should this strategy be implemented in EFL classes? The Virtual Reality presents an opportunity of learning with a real situation, but artificially created facilitating the visualization and the interaction sensation with the study focus. When we can't have the real experiences, the Virtual Reality is irreplaceable. The simulation in the VR also permits us to be in hard and dangerous situations, which aren't usually accessible in the real world. Furthermore, the VR permits to take to the students complex themes of hard learning and sometimes impossible to show. As explained above, VR can give the students a real example of things that they rarely see in their environment. For example: They never see snow, VR is able to create it and able to give the situation where it comes. This tool is able to make students feel the "real" things that is impossible to feel in their surroundings..

\section{REFERENCES}

Freina , L. \& Ott, M., 2015. A Literature Review on Immersive Virtual Reality in Education. United States, s.n., pp. 133-141.

Khan, I. A., 2016. "Difficulties in Mastering and Using ESP (Medical Vocabulary): A Linguistics Analysis of Working Saudi Hospital Professional. International Journal of Education" (article) (serial online) [cited 2018 July 14] available from: https://www.researchgate.net/profile/ Intakhab_Khan2/publication/297918 473_Difficulties_in_Mastering_and_ Using_English_for_Specific_Purpos e_Medical_Vocabulary_A_Linguisti c_Analysis_of_Working_Saudi_Hos pital_Professionals/links/56e47f1608 ae98445c1ef68f.pdf

Kurt, M. \& Bensen, H., 2017. "SIx Seconds to visualize the word: improving EFL learners' vocabulary through VVVs" (article) (serial online) [cited 2018 July 14] available from:

https://onlinelibrary.wiley.com/doi/a bs/10.1111/jcal.12182

Lie, A., 2007. "Education policy and EFL curriculum in Indonesia: Between the commitment to competence and quest for higher test scores" (article) (serial online) [cited 2018 July 14] available from: http://www.teflin.org/journal/index.p hp/journal/article/view/48

Madini, A. A., 2017. "Virtual Reality for Teaching ESP Vocabulary: A Myth of A Possibility" (article) (serial online) [cited 2018 July 14] available from:

https://www.researchgate.net/profile/ Abeer_Madini/publication/32040319 2_Virtual_Reality_for_Teaching_ES P_Vocabulary_A_Myth_or_A_Possi bility/links/59ede7dfa6fdccbbefd20e 1e/Virtual-Reality-for-TeachingESP-Vocabulary-A-Myth-or-APossibility.pdf 
Minocha, S., 2015. "The State of Virtual Reality in Education -Shape of Things to Come" (article) (serial online) [cited 2018 July 14] available from:

http://www.indianjournals.com/ijor.a spx?target $=$ ijor:ijer $\&$ volume $=4 \&$ issu $\underline{\mathrm{e}=11 \& \text { article }=004}$

Nurkamto, J., 2003. "Problema pengajaran bahasa Inggris di Indonesia" (article) (serial online) [cited 2018 July 14] available from: http://journal.umy.ac.id/index.php/F $\underline{\text { TL/article/view/3208 }}$

Omieno, K. K., Wabwoba, F. \& Matoke, N., 2013. "Virtual Reality in Education: Trends and Issues" (article) (serial online) [cited 2018 July 14] available from: http://erepository.kibu.ac.ke/handle/1 23456789/321
Songbatumis, A. M., 2017. "Challenges in Teaching English Faced by English Teachers at MTsN Taliwang, Indonesia" (article) (serial online) [cited 2018 July 14] available from:

http://journal.umy.ac.id/index.php/F TL/article/view/3208

Susilo, 2015. "Curriculum of EFL Teacher Education and Indonesian Qualification Framework: A Blip of the Future Direction" (article) (serial online) [cited 2018 July 14] available from: $\quad$ https://journal1.iainsamarinda.ac.id/index.php/dinamika ilmu/article/view/98

Yaseen, B. \& Shakir, H., 2015. "Movies Effects on EFL Learners at Iraqi Schools in Kuala Lumpur" (article) (serial online) [cited 2018 July 14] available from: https://eric.ed.gov/?id=EJ1149269 